\title{
Self-Awareness of Testicular Cancer among Mansoura Male University
}

\section{Students}

\author{
Mohamed Mustafa Abd Algany, Demonstrator \\ Community Health Nursing, Faculty of Nursing, Mansoura University \\ Sahar Mohammed Soliman, Assistant Professor \\ Community Health Nursing, Faculty of Nursing, Mansoura University
}

\author{
Samar El Hosieny Abdel-Raoof, Assistant Professor \\ Community Health Nursing, Faculty of Nursing, Mansoura University
}

\begin{abstract}
Cancer of the testis is the most common form of cancer among men aged 15-35 years and its incidence is increasing. This form of cancer is easily diagnosed by testicular selfexamination and is a highly treatable disease if detected early. Adolescent and young adult males must be taught to perform TSE as a normal routine health promotion activity. Objective: To assess Self-Awareness of Testicular Cancer among Mansoura Male University Students. Settings: 16 faculties affiliated to Mansoura University. Subjects: The sample size comprised 424 male students. Tools: Four tools were used in this study the first one Socio Economic Scale was adopted from Fahmy and El-Sherbini Socio Economic Scale, and modified by El Gelany, El-Wehady and El-Wasify, the following three tools were developed by researcher after reviewing the relevant literatures, tool two and three were developed to assess students' knowledge and their subjective practice related to testicular cancer and the fourth one was developed to assess students' attitudes and culture impact of their practices toward testicular self-examination. Results: Most of students showed poor knowledge about testicular cancer (TC) and improper practice of testicular self-examination. There is statistically significant relation between the studied students' level of knowledge and their academic year, and there is a positive significant relation between students' knowledge and their attitude. Conclusion: The main conclusion drawn from the current study is that the majority of students had poor knowledge and poor subjective practices related to testicular cancer and its preventive measures. Concerning students' attitude, most students reported that testicular cancer is a sever disease and testicular self-examination is very useful for early detection of this disease. Recommendation: It is recommended to conduct health education program to university male students focusing on improving their knowledge about TC and the importance of TSE practice for the early detection. Public health campaigns about testicular cancer and its preventive practices must be conducted for men.
\end{abstract}

Keywords: Testicular cancer, Preventive practices, Knowledge, Practice, Attitude, Male students.

\section{Introduction}

Testicular cancer (TC) is a form of cancer that develops and attacks the male sex organ. The most prevalent form of testicular cancer, germ cell tumors, forms in the cells responsible for the production of sperm. TC can also form in the cells that produce hormones in the testes and can also spread from other areas of the body to the testicles ${ }^{(1)}$.

TC is the most common form of cancer among young men aged 15-35 years and the incidence is rising. It is a highly 
treatable disease if detected in its early stage. American Cancer Institute (2015) ${ }^{(2)}$ revealed that the age-adjusted incidence rate was 5.6 per 100,000 men per year in 20082012. In Egypt the relative incidence rate is 0.5 per 100,000 in Lower Egypt, 0.5 per 100,000 in middle Egypt and 0.4 per 100,000 in Upper Egypt ${ }^{(3)}$.

TC is a curable disease when diagnosed early. Early diagnosis of the disease can be possible by assessing an unusual mass or swelling with self and regular examination of the testis. Early diagnosis plays an important role especially in nonseminomas or more aggressive and rapidly progressing testicular tumors ${ }^{(4,5)}$.

Research suggests high potentials of using low cost technique for early detection of testicular cancers ${ }^{(6,7)}$ such as testicular self-examination (TSE). For this reason it is important to raise community awareness of $\mathrm{TC}$, to focus on early diagnosis, surveillance subjects and educate TSE for male.

Attitudes, health beliefs, and health habits may influence certain disease outcomes. An individual's ability and willingness to change or alter certain lifestyle habits may have a direct effect on disease prevention or at least diminish the severity of the disease. Individual responsibility is part of health promotion. Health promotion encourages an individual to assume responsibility for monitoring his own health state ${ }^{(8)}$.

$\mathrm{TC}$ is an area that raises individual responsibility for early detection by selfscreening and early treatment to decrease mortality. Adolescent and young adult males must be taught to perform TSE as a normal routine health promotion activity. The media must be involved in the promotion of TSE as it has been with breast selfexamination (BSE). The public needs to be educated that early detection may reduce the serious and potentially fatal consequences of malignancy ${ }^{(9)}$.

The time surrounding diagnosis and treatment can be extremely stressful for the person, his family and friends. Supportive nursing interventions of the patient diagnosed with TC are numerous and important. Education should begin immediately and be reinforced frequently with these patients, focusing on the disease process, the specific treatment that the patient will undergo, and any side effects that might be encountered. Nurses are playing vital role in early detection and screening of the diseases. They can use a variety of teaching and learning methods to disseminate information about the disease and can help mass media and local advertisement to inform the target population of the disease prevention ${ }^{(10)}$.

Testicular cancer screening should take place at any setting in which nurses are employed, ranging from physician offices, schools, as well as industrial, community, chronic and acute care settings. It is a common misconception that cancer screening is limited to cancer detection clinics and should only be done by physicians and nurse practitioners. Cancer statistics mandate that cancer screening occur in a multiplicity of settings and not be limited to cancer screening clinics, comprehensive cancer centers, or large urban medical centers ${ }^{(11)}$.

In Egypt, although much attention was given to education on breast cancer and BSE, almost no study has been done for TC education and testicular self examination. Because the university students are mostly the target age group of testicular cancer incidence.

\section{Aim of the Study}

To assess Self-Awareness of Testicular Cancer among Mansoura Male University students. 
Materials and Method

Materials

Design: Cross sectional design was used.

Settings: This study was carried out on male students enrolled in the different faculties affiliated to Mansoura University, these include 16 faculties:

- Medical faculties were including:

Faculty of Medicine, Faculty of Dentistry, Faculty of Pharmacy, Faculty of Veterinary and Faculty of Nursing.

- Non-medical faculties were including:

Faculty of Science, Faculty of Engineering, Faculty of Agriculture, Faculty of Computing and information technology, Faculty of Arts, Faculty of Commerce, Faculty of Education, Faculty of Law, Faculty of Specific Education, Faculty of Tourism and Hotels, and Faculty of Physical education

Subjects: The students selected from the above mentioned settings and fulfilling the following criteria:

- Undergraduate students enrolled in the first and final study year during academic year 2014-2015.

- Age from 18 up to 25 years old.

Sampling:

Sample size:

-The sample size comprised 424 students, calculated for the cross- sectional design (to explore students' knowledge, practices and attitudes in relation to testicular cancer), as follows; When the Confidence limit $=5 \%$,

Population size $=20106$ students registered at Mansoura university, confidence level $=95 \%$, desired precision $=4 \%$, expected prevalence of correct knowledge and practices about testicular cancer $=50 \%$ and design effect $=1^{(12)}$.

-Proportion allocation technique was used to select the required students' number from the first and final year at studied faculties, using simple random sample technique (table 1).
Tools: Data were collected by using the following four tools:

\section{Tool I: El Gelany Socio-economic Scale}

This tool was adopted from El Gelany et al. $(2012)^{(13)}$ and included demographic characteristics of the studied students such as age, residence, marital status, faculty and academic year. In addition to socio economic level of students' family: this includes seven domains: background education, occupation, residency, monthly income, family possession, home sanitation and health care access. The total score was 84. Socio-economic level was estimated and scored as the following:

- 1-21 points mean low socioeconomic level.

- 22-42 points mean middle socioeconomic level.

- 43-63points mean high socioeconomic level.

- 64 points or more were identified mean very high socio-economic level.

Tool II: Structured Questionnaire to Assess Students' Knowledge regarding Testicular Cancer

This questionnaire was used to explore the students' knowledge regarding TC and its preventive practices. It included the following items; Definition of (testis and testicular cancer), age of incidence, signs and symptoms and risk factors of testicular cancer, Diagnosis measures, treatment and prevention of testicular cancer, and Testicular self-examination.

The questionnaire covered students' knowledge about TC and its preventive practices, it is composed of 17 questions (10 multiple choice and 7 fill in the blank questions) one mark was awarded for each correct response. 
Tool III: Structured Questionnaire to Assess Students' Subjective Practices related to Testicular Self-examination

This questionnaire was used to assess the students' subjective practice of TSE. This consisted of four questions about TSE, source of information, and frequency of performing TSE, Causes of not performing TSE and How to perform TSE.

Tool IV: Structured Questionnaire to Assess Students' Attitudes and Culture Impact of their Practices toward Testicular Self-examination

This questionnaire was used to assess Students' attitude toward TC and TSE based on health believe model. This tool consists of 27 statements requiring a response on a 4 point Likert rating scale with 4 continuum (strongly agree, agree, disagree, strongly disagree). A scoring system was used to quantify the students' attitude 4 marks were given to strongly agree, 3 marks to agree, 2 to disagree and 1 mark to strongly disagree. If the statements were negative, the scoring system was reversed in SPSS as one mark was given to strongly agree, two marks were given to agree, three marks to disagree, and four marks to strongly disagree, which made up a total score of 108 marks as the following:

1- Severity of TC (included 9 items $=36$ marks).

2- Benefits of TSE (included 10 items $=40$ marks).

3- Barriers of practicing TSE (included 8 items $=32$ marks).

\section{Method}

This study was accomplished throughout two main stages

\section{Preparation stage:}

\section{Administrative process}

- An official letter from the Faculty of Nursing was submitted to the deans of Facilities of Mansoura University to obtain their approval for conducting the study.

- Each dean was informed about the purpose of the study and the study process in order to gain their cooperation and support during data collection.

\section{Literature review}

- Review of national and international literatures on the various aspects of the testicular cancer and its preventive measures using scientific published articles, internet search and textbooks. This review was a guide for developing the study tools.

\section{Developing of the study tools}

- The following tools (II, III and IV) were developed by the researcher based on reviewing the relevant literature.

- Validity testing was done to the tools by submitting the tools to experts in "community health nursing, nursing education in addition to statistics ". Their recommended modifications were done.

- Reliability of these tools was tested by using Cronbach's alpha test in spss v16 as the following:-

- The reliability of the attitude scale as measured by using the Cronbach's alpha test was 0.85 .

- Tool II total scores of knowledge is 41 marks as the following:-

1-Definition (testis and testicular cancer), function of testis and types of testicular tumors (It includes 6 items $=6$ marks).

2- Age of incidence, signs and symptoms and risk factors of testicular cancer (It includes 14 item=14 marks).

3-Diagnosis, treatment and prevention of testicular cancer (It includes 12 items $=12$ marks).

4-Testicular self-examination (definition and importance, conducting of TSE, proper time to Perform TSE, proper interval to perform TSE, abnormal things 
found during TSE and tools used during TSE) (It includes 9 items $=9$ marks).

The knowledge level was categorized into three categories:

Poor $=$ scores less than $50 \%$ of total scores (0- less than 20.5)

Fair $=$ scores $50 \%$ to $75 \%$ of total sores (20.5- less than 30.75)

Good $=$ scores more than $75 \%$ of total scores (more than 30.75).

\section{Pilot study}

A Pilot study was conducted on $10 \%$ of students (43 students) these selected randomly from the same settings and excluded from the studied sample to evaluate the clarity, applicability, and reliability of the research tools and estimate the approximate time required for data collection. Accordingly the necessary modification was done, some questions were added and others were clarified or omitted.

\section{Operational stage:}

\section{Data collection}

The study was conducted from end of September 2014 to the middle of December 2014.

The researcher introduced himself to the students and gave them a brief orientation about aim of the study in order to gain their cooperation.

The questionnaires were distributed to the students at their faculties in clinical room and collected immediately after completion.

\section{Ethical considerations:}

- Ethical approval was obtained from the Research Ethics Committee of Faculty of Nursing, Mansoura University.

- The student's oral approval was taken before the beginning of the study and the students were informed about the study purpose and were assured that their identities and responses to the questionnaire would be confidential and will be used only for research purpose.

- Students have the right to participate or not in the study and they can withdraw at any time.

\section{Statistical Analysis}

- Data were sorted, coded, organized, categorized and then transferred into especially designed formats.

- Data were analyzed using SPSS (Statistical Package for Social Sciences) version 16.

\section{Results}

Demographic characteristics of studied students:

Table (2) reveals that the mean age of the studied students was $19.68 \pm 1.64$ years. More than half $58 \%$ of them lived at rural areas. The majority $98.6 \%$ were single. Almost two thirds $65.1 \%$ belonged to middle socio economic level, and only $11.1 \%$ belonged to low socio economic level.

Knowledge of studied students about testicular cancer and testicular self examination:

Table (3) reveals that $18.2 \%$ of studied students, less than two thirds $(63.4 \%)$ and $23.6 \%$ of them knew the definition, function of testis as sperm cell development and secretion of male hormones respectively. Moreover, more than $79.5 \%$ and less than $19.6 \%$ of them stated that cancer can affect the testis and there are two types of testicular tumors respectively.

Almost one third $32.5 \%$ of students and $26.2 \%$ of them knew the definition and incidence of TC, respectively.

Concerning risk factors of $\mathrm{TC}$, the highest percentage of the students $61.1 \%$ belonged to immunodeficiency viruses 
(AIDS); while the lowest percentage $15.8 \%$ stated that it is belonged to trauma of testis.

In relation to signs and symptoms of $\mathrm{TC}$, $45.3 \%$ of students revealed pain of testis and scrotum, $42 \%$ of them stated pain or burning during urination, while $23.3 \%$ mentioned gynecomastia.

Concerning testicular cancer diagnosis, table 4 clarifies that $41.3 \%$ of students knew that TC can be diagnosed by physician examination, followed by $35.8 \%$ reported radiological examination, while $28.3 \%$ of them mentioned TSE.

Regarding treatment of $\mathrm{TC}$, less than half $41.3 \%$ of the studied students' stated surgical intervention, while almost- one third $34.7 \%$ and $25.9 \%$ of them mentioned chemotherapy and radiotherapy respectively as TC treatment.

In relation to prevention of TC, $55.7 \%$ of students revealed avoid smoking, 39.4\% reported radiological screening on pelvic area and $32.8 \%$ of them mentioned TSE.

Table (5) shows that only $6.1 \%, 4.5 \%$, $16.5 \%$ and $17.9 \%$ of studied students knew TSE and its importance in detecting TC, described steps of TSE, identified TSE time and the proper interval duration of conduction respectively.

Concerning abnormalities which can be founded during TSE, $19.3 \%$ of studied students revealed that large size of one or both testicles, $8 \%$ appearance of lump, $4 \%$ change of scrotm skin color and $3.8 \%$ pain in testis. Moreover, only $0.7 \%$ of studied students mentioned the equipment used for TSE.

Table (6) presents that the majority $96.2 \%$ of the studied students showed poor score level of knowledge related to TC as the following; $80.9 \%$ had poor score level of knowledge related to general information, $94.8 \%$ of them had poor score level of knowledge related to risk factors.

In addition, $88.9 \%$ of students had poor score level of knowledge related to signs and symptoms, $94.3 \%$ of them had poor score level of knowledge related to TC diagnosis and the total score of students' knowledge was poor $79.5 \%$ related to prevention of TC. However; only $2.4 \%$ of them showed good score level of knowledge.

Table (7) shows frequency of performing TSE, $0.9 \%$ of them performed the process only once through their life, while $2.4 \%$ and $1.1 \%$ were performed TSE two times and three times or more respectively during their life.

It was found that $95.5 \%$ of students didn't practice TSE, while only $4.5 \%$ of them practice TSE.

Regarding attitude of students toward testicular cancer and testicular self examination, table (8) reveals that the mean score was $81.32 \pm 6.39$, which indicated high positive direction of the students.

Regarding severity of TC, students reported that TC is very severing with mean scores of $28.39 \pm 2.96$.

In relation to benefits of TSE, most students indicated that TSE is the most important benefit in early detection of TC with mean scores of $33.38 \pm 3.36$.

Concerning barriers of performing testicular self-examination, slightly more than half of the studied students have barriers to do this examination with mean scores of $19.53 \pm 3.54$.

Table (9) shows that there was no statistically significant relation between the studied students' level of knowledge and their residence and social class. But there is statistically significant relation between the studied students' level of knowledge and their academic year.

Table (10) shows that there was no statistically significant difference between students' attitude related to their residence, academic year.

Table (11) shows that there was a positive significant coefficient relation between students' knowledge and their 
attitude, but there was no statistically significant relation between the students' attitude and their social class.

\section{Discussion}

Being a man or a woman has a significant impact on health, as a result of both biological and gender-related differences. Testicular cancer accounts for $1 \%$ of all malignant neoplasms among males. However, among young men, it is relatively common tumors represents $25 \%$ of all cancers among young men aged 15-35 years ${ }^{(14)}$. TC show excellent cure rates, when detecting early by testicular selfexamination (TSE) that is the method for early detection of the physical abnormalities in the testis ${ }^{(15)}$.Therefore, the American Medical Association and the American Urological Association promote and support public awareness and education of TSE for early detection of TC.

The present study revealed that, the mean age of the students' was19.7 \pm 1.64 years (range 18-25) this finding was consistent with the mean age $18.7 \pm 1.1$ years (range 17-25) of students at 12 different medical schools in Turkey ${ }^{(16)}$. Similarity of both studies clarified the vulnerability of this age group.

As regarding to the level of knowledge, the present study showed poor score level of knowledge regarding to TC \& TSE among the majority of students. This study was in agreement with three different studies in different countries which revealed poor knowledge regarding TC \& TSE among university students, the first study was conducted at three universities in the Port Harcourt metropolitan $\operatorname{area}^{(17)}$, the second study was in Ankara, Turkey ${ }^{(18)}$ and the third one was in Ugandan University ${ }^{(19)}$. Lack of knowledge of testicular cancer and testicular self-examination may be related to various reasons. Firstly, these topics were not among the students' concerns. Secondly, absence of these educational topics in educational curriculums through the previous educational academic study years and negligence of these previous topics in health care settings and media.

The finding of the present study illustrated that; nearly one third of students knew TC and a quarter of them had knowledge about the incidence age. These findings were in the same line with the findings of study conducted in Ankara, Turkey ${ }^{(18)}$ reported that almost half of the students have knowledge about testicular cancer and most of them didn't have information about the incidence age while the finding of study in a single Irish banking Institution $^{(7)}$ reported that the majority of studied men aware of the TC incidence age.

On the other hand, the majority of students in the present study having no knowledge about risk factors, signs and symptoms of TC. These finding were consistent with other studies findings the first study conducted at 5 senior high schools from 3 medium-sized cities in a region in Mid-Sweden ${ }^{(4)}$, the second one was conducted at the Faculty of Health Sciences in University in Ankara ${ }^{(20)}$ and the third one conducted in Ugandan University ${ }^{(19)}$ they reported that the majority of students didn't know the signs \& symptoms and risk factors of testicular cancer. However, other study was conducted in a Single Irish Banking Institution $^{(7)}$ clarified that the majority of male employees were more aware of potential symptoms and risk factors of testicular cancer. This finding was different may be because of high profile public figures with TC and wider availability of educational materials.

Concerning diagnosis of testicular cancer, the current study demonstrated that the majority of the studied students didn't know screening procedures of testicular cancer, less than half of them knew that testicular cancer can be diagnosed by physician examination, followed by more than one third reported radiological examination, while more than a quarter mentioned TSE. These results at the same line with the result of the study conducted in 
the northeast United States ${ }^{(21)}$ which clarified that participant university men are generally uninformed on TC risk and screening procedures.

Moreover, Studies conducted in three tertiary institutions in Port Harcourt ${ }^{(17)}$, university located in Ankara, Turkey ${ }^{(18)}$, private and governmental hospitals in urban Kayseri, Turkey ${ }^{(22)}$ and 5 senior high schools from 3 medium-sized cities in a region in mid-Sweden ${ }^{(4)}$ were revealed that most respondents of their studies had never heard about testicular self-examination as a method of early diagnosis. Also studies done in Oredo Local Government Area (OLGA), Edo State, Nigeria ${ }^{(23)}$ stated that nearly all the male students had never heard about testicular self-examination, However, only $5.6 \%$ of male adolescents have information about testicular selfexamination in 5 senior high schools from 3 medium-sized cities in a region in midSweden $^{(4)}$, and $1.2 \%$ of young college students, academic and nonacademic staff and local artisans within three universities and colleges in the Port Harcourt metropolitan area have been taught about testicular self-examination ${ }^{(17)}$. In contrast to these results, study conducted in Australia ${ }^{(24)}$ stated that $58.4 \%$ out of the 101 respondents had heard of testicular selfexamination before the survey.

The present study showed that the most study sample didn't know the appropriate time of performing testicular selfexamination, this result agree with result of study conducted in Uganda ${ }^{(19)}$, which explored that $71 \%$ of participants didn't know the most appropriate time for testicular self-examination.

The executed study reported that the majority of studied sample didn't know the abnormalities which may be detected during testicular self-examination, especially a lump on the testicles as a major sign and intense pain as a common symptom of testicular cancer. These results agree with most studies in region in mid-Sweden ${ }^{(4)}$, Ugandan University ${ }^{(19)}$, and University in
Ankara $^{(20)}$ stated that most participants didn't have information about signs and symptoms of testicular cancer or the lump on testicles as a sign of testicular cancer.

Regarding treatment of testicular cancer, the present study revealed that the majority of the studied students had poor knowledge about treatment modalities of testicular cancer. Less than half of them stated that testicular cancer can be treated by surgical intervention, while nearly one third and a quarter of students stated that chemotherapy and radiotherapy respectively treat TC. These results agree with a study conducted in region in mid-Sweden (4), reported that most male adolescents have limited knowledge about treatment of testicular cancer; more than $40 \%$ didn't know the treatment by surgery and nearly half of them didn't know that testicular cancer can be treated with radiotherapy.

As regards to TSE practice, the present study explored that most of the studied students didn't learn about testicular selfexamination, therefore most of them didn't perform it, and this means that the majority of students had poor knowledge related practice TSE. These results were in the same line with other studies which revealed that the minority of students $4.7 \%$ in the Etimesgut Armoured Units Education Center Commandership ${ }^{(25)}, 11.5 \%$ of students in 5 senior high schools from 3 medium-sized cities in a region in midSweden $^{(4)}, 1.0 \%$ of students in three tertiary institutions in Port Harcourt ${ }^{(17)}$, and $2.5 \%$ of students at 12 different medical schools in Turkey ${ }^{(16)}$ had performed TSE.

From the researcher point of view, lack of practicing testicular self-examination related to lack of students' knowledge about testicular cancer (TC) and testicular selfexamination (TSE), lack of knowledge related subject and the effects of cultural structure, attitude and beliefs could be hinder them to perform TSE.

Regarding students attitude, the present study showed that students considered 
testicular cancer as a sever disease which may affect their health negatively with mean scores of $(28.39 \pm 2.96)$. There was positive significant coefficient correlation between level of knowledge and attitude. These results were agreed with a study conducted in university located in Ankara, Turkey $^{(18)}$ on students and study on technicians working at private and governmental hospitals in urban Kayseri ${ }^{(26)}$ which illustrated that testicular cancer is a very serious disease, and they were afraid of getting testicular cancer.

When assessing challenges that facing studied students, the current study showed that slightly more than half of them against testicular self-examination performance, because the culture prohibit this examination, it's very difficult task, and feeling iniquity and guilt toward performing this examination.

In this study, although the majority of the students reported lack of TC/TSE knowledge and awareness, they stated vague and contradictory judgments about TC and about the value of TSE as a tool to fight cancer. Students overwhelmingly indicated that there was value and personal benefit in performing testicular selfexamination. Furthermore, they felt that performing TSE was a responsible thing to do. These data suggest that although students didn't specifically know about TC and TSE, they are optimistic and willing to perform TSE, but this point should be taken with caution because the students may want to please the researcher by indicating a positive attitude toward testicular cancer and TSE.

\section{Conclusion}

The main conclusion drawn from the present study is that, most of students had poor knowledge and poor subjective practices related to testicular self examination. Concerning students' attitude, most students reported that testicular cancer is a sever disease and testicular self examination is important process to detect TC early. There was statistically significant relation between the studied students' level of knowledge and their academic year and there was a positive significant coefficient between students' knowledge and their attitude.

\section{Recommendation}

It is recommended from this study to conduct health education program to university male students focusing on improving their knowledge about TC and practice TSE for the early detection. The college environment is ideal place to implement intervention strategies that incorporate the messages about testicular cancer; there fore this topic is very important to be included into curriculum. 
Table (1): Distribution of recruited subjects $(n=424)$ according to different faculties of Mansoura University

\begin{tabular}{||l|c|c|c|c||}
\hline \multirow{2}{*}{ Faculty } & \multicolumn{2}{|c|}{ Actual numbers } & \multicolumn{2}{c|}{ Selected numbers } \\
\cline { 2 - 5 } & $\begin{array}{c}\text { First } \\
\text { academic } \\
\text { year }\end{array}$ & $\begin{array}{c}\text { Final } \\
\text { academic } \\
\text { year }\end{array}$ & $\begin{array}{c}\text { First } \\
\text { academic } \\
\text { year }\end{array}$ & $\begin{array}{c}\text { Final } \\
\text { academic } \\
\text { year }\end{array}$ \\
\hline Medical faculties & 478 & 516 & 10 & 11 \\
\hline Medicine & 466 & 350 & 10 & 7 \\
\hline Pharmacy & 211 & 128 & 5 & 3 \\
\hline Veterinary & 178 & 203 & 4 & 4 \\
\hline Dentistry & 172 & 44 & 4 & 1 \\
\hline Nursing & \multicolumn{5}{|l|}{} \\
\hline Non-medical faculties & 3282 & 1194 & 68 & 25 \\
\hline Commerce & 2946 & 1419 & 61 & 29 \\
\hline Law & 1904 & 1246 & 39 & 26 \\
\hline Engineering & 1481 & 638 & 31 & 13 \\
\hline Arts & 700 & 151 & 15 & 4 \\
\hline Physical education & 564 & 147 & 12 & 3 \\
\hline Science & 471 & 109 & 10 & 3 \\
\hline $\begin{array}{l}\text { Computing and } \\
\text { information technology }\end{array}$ & 456 & 18 & 10 & 1 \\
\hline Agriculture & 318 & 51 & 7 & 1 \\
\hline Education & 132 & 27 & 3 & 1 \\
\hline Tourism and Hotels & 80 & 26 & 2 & 1 \\
\hline Specific education & & & \\
\hline \hline
\end{tabular}

Table (2): Distribution of studied students according to their socio demographic characteristics

\begin{tabular}{|c|c|c|}
\hline Items & $\mathrm{N}=424$ & $\%$ \\
\hline $\begin{array}{l}\text { Age (years) } \\
18-<21 \\
21-25 \\
\end{array}$ & $\begin{array}{l}290 \\
134 \\
\end{array}$ & $\begin{array}{l}68.4 \\
31.6 \\
\end{array}$ \\
\hline Mean \pm SD & \multicolumn{2}{|c|}{$19.68 \pm 1.64$} \\
\hline $\begin{array}{l}\text { Residence } \\
\text { Rural } \\
\text { Urban }\end{array}$ & $\begin{array}{l}246 \\
178 \\
\end{array}$ & $\begin{array}{l}58.0 \\
42.0 \\
\end{array}$ \\
\hline $\begin{array}{l}\text { Marital status } \\
\text { Single } \\
\text { Married }\end{array}$ & $\begin{array}{c}418 \\
6\end{array}$ & $\begin{array}{c}98.6 \\
1.4\end{array}$ \\
\hline $\begin{array}{l}\text { Socioeconomic Levels } \\
\text { - Low socio-economic level } \\
\text { - Middle socio-economic level } \\
\text { - High socio-economic level } \\
\end{array}$ & $\begin{array}{c}47 \\
276 \\
101 \\
\end{array}$ & $\begin{array}{l}11.1 \\
65.1 \\
23.8 \\
\end{array}$ \\
\hline
\end{tabular}


Table (3): Distribution of the students according to their knowledge about testicular cancer

\begin{tabular}{|c|c|c|}
\hline Items & $\mathrm{N}=424$ & $\%$ \\
\hline Definition of testis & 77 & 18.2 \\
\hline \multicolumn{3}{|l|}{ Function of testis } \\
\hline Sperm cell development & 269 & 63.4 \\
\hline Secretion of male hormones & 100 & 23.6 \\
\hline \multicolumn{3}{|l|}{ Epidemiology of TC } \\
\hline General information & & \\
\hline Occurrence of cancer in testicles & 337 & 79.5 \\
\hline Types of testicular tumors & 83 & 19.6 \\
\hline Definition of testicular cancer & 138 & 32.5 \\
\hline Testicular cancer incidence age & 111 & 26.2 \\
\hline \multicolumn{3}{|l|}{ Risk factors of TC* } \\
\hline Acquired immunodeficiency viruses(AIDS) & 259 & 61.1 \\
\hline Klinfilter syndrome & 141 & 33.3 \\
\hline Cryptorchidism & 125 & 29.5 \\
\hline Personal history & 116 & 27.4 \\
\hline Family history & 90 & 21.2 \\
\hline Trauma of testis & 67 & 15.8 \\
\hline \multicolumn{3}{|l|}{ Signs and symptoms of TC* } \\
\hline Pain of testis and scrotum & 192 & 45.3 \\
\hline Pain or burning sensation during urination & 178 & 42.0 \\
\hline Enlargement of testis or lumps & 173 & 40.8 \\
\hline Loss of weight & 149 & 35.1 \\
\hline Back or abdominal pain & 147 & 34.7 \\
\hline Feeling of heaviness in scrotum & 143 & 33.7 \\
\hline Gynecomastia & 99 & 23.3 \\
\hline
\end{tabular}

*More than one answer

*Testicular cancer (TC) 
Table (4): Distribution of the students according to their knowledge related to diagnosis, treatment and prevention of testicular cancer

\begin{tabular}{|l|c|c|}
\hline Items & $\mathbf{N = 4 2 4}$ & \% \\
\hline $\begin{array}{l}\text { Diagnosis of testicular cancer* } \\
\text { Medical examination of testis }\end{array}$ & 175 & 41.3 \\
\hline Radiological examination & 152 & 35.8 \\
\hline Blood testing & 138 & 32.5 \\
\hline Testicular self-examination & 120 & 28.3 \\
\hline $\begin{array}{l}\text { Treatment of testicular cancer* } \\
\text { Surgical }\end{array}$ & 175 & 41.3 \\
\hline Chemotherapy & 147 & 34.7 \\
\hline Radiotherapy & 110 & 25.9 \\
\hline $\begin{array}{l}\text { Prevention of testicular cancer* } \\
\text { Avoid smoking }\end{array}$ & 236 & 55.7 \\
\hline Avoid unhealthy food & 189 & 44.6 \\
\hline Radiological screening on pelvic area & 167 & 39.4 \\
\hline Performing testicular self-examination & 139 & 32.8 \\
\hline Avoid strenuous physical activity & 78 & 18.4 \\
\hline
\end{tabular}

Table (5): Distribution of studied students according to their knowledge related to Testicular self-examination

\begin{tabular}{|l|c|c||}
\hline Items & $\mathbf{N = 4 2 4}$ & \% \\
\hline Information about testicular self-examination & & \\
\hline TSE and its importance for detecting testicular cancer & 26 & 6.1 \\
\hline Describing steps of TSE & 19 & 4.5 \\
\hline Identify TSE time & 70 & 16.5 \\
\hline Identify interval duration of conducting TSE & 76 & 17.9 \\
\hline $\begin{array}{l}\text { Abnormal detection during TSE } \\
\text { 1- The large size of one or both testis. }\end{array}$ & 82 & 19.3 \\
\hline 2- The appearance of lump on the testis. & 34 & 8.0 \\
\hline 3- Change skin color of scrotm. & 17 & 4.0 \\
\hline 4- Testis pain & 16 & 3.8 \\
\hline Preparation steps to conduct TSE & 3 & 0.7 \\
\hline
\end{tabular}


Table (6): Distribution of studied students regarding their total score level of knowledge about testicular cancer

\begin{tabular}{|c|c|c|}
\hline \multirow[b]{2}{*}{ Items } & \multicolumn{2}{|c|}{$(\mathrm{N}=424)$} \\
\hline & $\mathbf{N}$ & $\%$ \\
\hline $\begin{array}{l}\text { Total knowledge score of general information } \\
\text { about TC } \\
\text { - Poor }\end{array}$ & 343 & 80.9 \\
\hline$\bullet \quad$ Fair & 68 & 16.0 \\
\hline - good & 13 & 3.1 \\
\hline $\begin{array}{l}\text { Total risk factors knowledge score } \\
\text { - Poor }\end{array}$ & 402 & 94.8 \\
\hline • Fair & 14 & 3.3 \\
\hline • Good & 8 & 1.9 \\
\hline $\begin{array}{l}\text { Total signs and symptoms knowledge score } \\
\text { - Poor }\end{array}$ & 377 & 88.9 \\
\hline - Fair & 44 & 10.4 \\
\hline$\bullet$ Good & 3 & 0.7 \\
\hline $\begin{array}{l}\text { Total diagnosis of testicular cancer knowledge } \\
\text { score } \\
\qquad \text { Poor }\end{array}$ & 400 & 94.3 \\
\hline - Good & 24 & 5.7 \\
\hline $\begin{array}{l}\text { Total treatment of testicular cancer knowledge } \\
\text { score } \\
\bullet \text { Poor }\end{array}$ & 360 & 84.9 \\
\hline - Fair & 51 & 12.0 \\
\hline • Good & 13 & 3.1 \\
\hline $\begin{array}{l}\text { Total prevention of testicular cancer knowledge } \\
\text { score } \\
\qquad \text { Poor }\end{array}$ & 337 & 79.5 \\
\hline - Fair & 62 & 14.6 \\
\hline$\bullet$ Good & 25 & 5.9 \\
\hline $\begin{array}{l}\text { Total information about TSE knowledge score } \\
\text { - Poor }\end{array}$ & 412 & 97.2 \\
\hline$\bullet$ Good & 12 & 2.8 \\
\hline $\begin{array}{l}\text { Total knowledge score of abnormal detection } \\
\text { during TSE } \\
\text { • Poor }\end{array}$ & 412 & 97.2 \\
\hline - Fair & 8 & 1.9 \\
\hline - Good & 4 & 0.9 \\
\hline $\begin{array}{l}\text { Total knowledge score (41 mark) } \\
\text { - Poor }\end{array}$ & 408 & 96.2 \\
\hline - Fair & 6 & 1.4 \\
\hline - Good & 10 & 2.4 \\
\hline
\end{tabular}

Poor $=$ scores less than $50 \%$ of total scores $(<20.5)$

Fair $=$ scores $50 \%$ to $75 \%$ of total sores $(20.5-30.75)$

Good $=$ scores more than $75 \%$ of total scores $(>30.75)$. 
Table (7): Distribution of the studied students according to their subjective practice of testicular self-examination

\begin{tabular}{|l|c|c||}
\hline Items & $\mathbf{N = 4 2 4}$ & \% \\
\hline Frequency of performing TSE during their life: & 4 & 0.9 \\
\hline Once & 10 & 2.4 \\
\hline Three times or more & 5 & 1.2 \\
\hline $\begin{array}{l}\text { Students performed the following steps of TSE: } \\
\text { 1- Stand in front of mirror, check for any change in color of scrotm skin. }\end{array}$ & 19 & 4.5 \\
\hline 2- Cup one testicle at a time using both hands & 19 & 4.5 \\
\hline 3- Examine by rolling the testicle between thumb and fingers & 19 & 4.5 \\
\hline 4- Familiarize themselves with the spermatic cord and epididymis & 19 & 4.5 \\
\hline 5- Feel for lumps, change in size or irregularities. & 19 & 4.5 \\
\hline
\end{tabular}

*TSE = testicular self-examination

Table (8): Mean \& Standard deviation of the studied students regarding to their attitude categories toward testicular cancer and its preventive practices

\begin{tabular}{|c|c|c|c|}
\hline \multirow[t]{2}{*}{ Attitude categories } & \multirow[t]{2}{*}{ Mean \pm SD } & \multicolumn{2}{|c|}{$\begin{array}{l}95 \% \text { confidence } \\
\text { interval of the } \\
\text { difference }\end{array}$} \\
\hline & & Lower & Upper \\
\hline Severity of testicular cancer(36 mark) & $28.39 \pm 2.96$ & 28.1158 & 28.6813 \\
\hline Benefits of testicular self-examination(40 mark) & $33.38 \pm 3.36$ & 33.0641 & 33.7047 \\
\hline $\begin{array}{l}\text { Barriers of performing testicular self-examination(32 } \\
\text { mark) }\end{array}$ & $19.53 \pm 3.54$ & 19.1955 & 19.8706 \\
\hline Total attitude (108) & $81.32 \pm 6.39$ & 80.7065 & 81.9256 \\
\hline
\end{tabular}


Table (9): Relation between the studied students' level of knowledge and their residence, academic year and social class

\begin{tabular}{|c|c|c|c|c|c|c|c|c|}
\hline \multirow{3}{*}{ Characteristics } & \multicolumn{6}{|c|}{ Level of Knowledge } & \multirow{3}{*}{$\chi^{2}$} & \multirow{3}{*}{$\mathbf{P}$} \\
\hline & \multicolumn{2}{|c|}{$\begin{array}{c}\text { Poor } \\
(<50 \%)\end{array}$} & \multicolumn{2}{|c|}{$\begin{array}{c}\text { Fair } \\
(50 \%-75 \%)\end{array}$} & \multicolumn{2}{|c|}{$\begin{array}{c}\text { Good } \\
(>75 \%)\end{array}$} & & \\
\hline & No & $\%$ & No & $\%$ & No & $\%$ & & \\
\hline \multicolumn{9}{|l|}{ Residence } \\
\hline - Urban & 171 & 96.1 & 2 & 1.1 & 5 & 2.82 & 0.45 & 0.99 \\
\hline - Rural & 237 & 96.1 & 4 & 1.6 & 5 & 0.0 & & \\
\hline \multicolumn{9}{|l|}{ Academic year } \\
\hline - Frist year & 285 & 99.0 & 3 & 1.0 & 00 & 0.0 & $22.75^{* *}$ & 0.00 \\
\hline - Final year & 123 & 90.4 & 3 & 2.2 & 10 & 7.4 & & \\
\hline \multicolumn{9}{|l|}{ Social class } \\
\hline - Low (1-21) & 47 & 100 & 0 & 0.0 & 0 & 0.0 & & \\
\hline - $\quad$ Middle (22-42) & 267 & 96.7 & 2 & 0.7 & 7 & 2.5 & 101 & \\
\hline - High (43-63) & 94 & 93.1 & 4 & 4.0 & 3 & 3.0 & & \\
\hline
\end{tabular}

** Statistically significant at $\mathrm{p} \leq 0.05$ 
Table (10): Mean difference of students' attitude toward testicular cancer, TSE and their residence, academic year and social class

\begin{tabular}{|c|c|c|c|}
\hline & $\begin{array}{l}\text { Attitude mean scores } \\
\qquad(\bar{X} \pm \text { S.D })\end{array}$ & T- test & $\mathbf{P}$ \\
\hline \multicolumn{2}{|l|}{ Residence } & \multirow{3}{*}{0.43} & \multirow{3}{*}{0.66} \\
\hline Urban & $81.15 \pm 6.87$ & & \\
\hline Rural & $81.43 \pm 6.02$ & & \\
\hline \multicolumn{2}{|c|}{ Academic year } & \multirow{3}{*}{0.782} & \multirow{3}{*}{0.43} \\
\hline First year & $81.14 \pm 6.37$ & & \\
\hline Final year & $81.66 \pm 6.42$ & & \\
\hline
\end{tabular}

Statistically significant at $\mathrm{p} \leq 0.05$

Table (11): Correlation between students' knowledge and their attitude and social class

\begin{tabular}{|l|c|c|}
\hline \hline Correlated items & \multicolumn{2}{|c|}{ Attitude } \\
\cline { 2 - 3 } & r & P \\
\hline Total knowledge & 0.11 & $\mathbf{0 . 0 1}$ \\
\hline Social Class & 0.02 & 0.74 \\
\hline
\end{tabular}

Statistically significant at $\mathrm{p} \leq 0.05$

$\mathrm{r}=$ Correlation Coefficient 


\section{References}

1. Castro JB. What Is Testicular Cancer? (2015). Available at: http://www.everydayhealth.com/testicul ar-cancer/. (Retrieved on: 26 July 2015).

2. American Cancer Institute. Testicular Cancer (2015). Available at: http://seer.cancer.gov/statfacts/html/testi s.html\#incidence-mortality. (Retrieved on: 29 July 2015).

3. Ibrahim AS, Khaled HM, Mikhail NNH, Baraka H, Kamel H. Cancer Incidence in Egypt: Results of the National Population-Based Cancer Registry Program. Journal of Cancer Epidemiology 2014; 18 pages.

4. Rudberg L, Nilsson S, Wikblad K, Carlsson M. Testicular cancer and testicular self-examination knowledge and attitudes of adolescent Swedish men. Cancer Nursing 2005; 28(4): 256262.

5. Wynd CA. Testicular self-examination in young adult men. Journal Nurs Scholarsh 2002; 34: 251-255.

6. McCullah J, Lewis G, Warlow C. Promoting awareness and practice of testicular self-examination. Nursing Standard 2005; 19: 41-49.

7. Casey R.G, Grainger R, Butler M.R, McDermott T.E, Thornhill J.A. Public Awareness of Testis Cancer and the prevalence of Testicular Selfexamination-changing patterns over 20 years. Urology 2010; 76: 915-918.

8. Institute of Medicine (US) Committee on Health and Behavior: Research, Practice, and Policy. Health and Behavior: The Interplay of Biological, Behavioral, and Societal Influences. Washington (DC): National Academies Press (US); 2001. 5, Individuals and Families: Models and Interventions. Available at:
http://www.ncbi.nlm.nih.gov/books/NB K43749/. (Retrieved on: 24 July 2015).

9. Ward K, Vander Weg M, Read M, Sell M, Beech B. Testicular cancer awareness and self-examination among adolescent males in a community-based youth organization. Preventive Medicine Journal 2005; 41: 386-398.

10. Brown CG. (2004) Testicular cancer: An Overview. Medscape, Washington. Available at: http://www.medscape.com/viewarticle/4 73629_9. (Retrieved on: 24 July 2015).

11. Stromborg MF. The Role of the Nurse in Cancer Detection and Screening. Seminars in Oncology Nursing; 1986; 2(3): 191-199.

12. Wayne W. Danial. Biostatistics: a foundation for analysis in health sciences. $5^{\text {th }}$ edition, John Wiley\& Sons. ISBN 19870;-471-52514: 1571.

13. El-Gilany A, El-Wehady A, El-Wasif M. Updating and validation of the socioeconomic status scale for health research in Egypt. Eastern Mediterranean Health Journal 2012; 18 (9): 962-968.

14. Shanmugalingam T, Soultati A., Chowdhury S, Rudman S, Van Hemelrijck M. Global incidence and outcome of testicular cancer. Clinical Epidemiology 2013; 5: 417-427. doi:10.2147/CLEP.S34430.

15. Testicular cancer Canada (2014) Early Detection of Testicular Cancer. Testicular Cancer Canada, Canada. Available at: http://testicularcancercanada.ca/index.p $\mathrm{hp} /$ learnabouttesticularcancer/earlydetet ion. (Retrieved on: 26 July 2015).

16. Kuzgunbay B, Yaycioglu O, Soyupak B, Kayis AA, Ayan S, Yavascaoglu I, Cal C, Beduk Y. Public awareness of testicular cancer and self-examination in 
Turkey: A multicenter study of Turkish Urooncology Society. Urologic Oncology 2013; 31, 386-391.

17. Ugboma HAA, Aburoma HLS. Public awareness of testicular cancer and testicular self-examination in academic environments: a lost opportunity. Clinics 2011; 66 (7), 1125-1128.

18. Ugurlu Z, Akkuzu, G, Karahan A, Beder A, Dogan N, Okdem S, Kav S. Testicular Cancer and Testicular SelfExamination among University Students. Asian Pacific Journal of Cancer Prevention 2011; 12, 695-698.

19. Muliira JK, Nalwanga PB, Muliira RS, Nankinga Z. Knowledge, Perceived risk and barriers to testicular selfexamination among male university students in Uganda. JMH 2012; 9(1), 36-44.

20. Altin R, Kav S. Testicular cancer and self-testicular examination knowledge And Practice among University Students. Uluslararası Üreme Sağlığı ve Aile Planlamas1 Kongresi, Bildiri Özetleri Kitab1, 256, Ankara, 19-22 Nisan 2007 (in Turkish).

21. Rovito MJ, Gordon TF, Bass SB, DuCette J. Perceptions of Testicular Cancer and Testicular Self-Examination Among college men: a report on intention, vulnerability, and promotional material preferences. American Journal of Men's Health 2011; 5 (6): 500-507.

22. Güleser GN, Unalan D. The knowledge, attitude and behaviors of healthy services vocational students on testicular cancer and testicular selfexamination. European Journal of Oncology Nursing 2010; 14, 35.

23. Onyiriuka AN, Imoebe FE. Testicular self-examination among Nigerian adolescent secondary school boys: knowledge, attitude and practices. J PREV MED HYG 2013; 54: 163-166.

24. Barling NR, Lehmann M. Young men's awareness, attitudes and practice of testicular self-examination: a health action process approach. Journal of Psychology, Health \& Medicine 1999; 4(3), 255-263.

25. Gocgeldi E, Kocak N, Ulus S, Yeginer $C$, Basal S. Investigation of the frequency of testicular self-examination performance in young adults' males. Journal of Gulhane Tip Derg 2011; 53, $17-25$.

26. Ozturk A, Unalan D, Guleser GH. Knowledge, Attitude and Practices of Technicians Working at Hospitals towards Testicular Cancer and Selfexamination of Testicles in Turkey. Asian Pac J Cancer Prev 2014; 15 (23), 10095-10099.

27. Cronholm PF, Mao JJ, Nguyen GT, Paris RT. A Dilemma in Male Engagement in Preventive Services: Adolescent Males' Knowledge and Attitudes toward Testicular Cancer and Testicular Self-Exam. American Journal of Men's Health 2009; 3(2), 134-140. 